\title{
INVESTMENT OPPORTUNITY SET AND GOOD CORPORATE GOVERNANCE TO EARNINGS QUALITY
}

\author{
Fransisca Listyaningsih \\ Universitas Mercu Buana
}

Article DOI: https://doi.org/10.36713/epra3955

\begin{abstract}
This study aims to examine the effect of good corporate governance mechanisms (consisting of institutional ownership and managerial ownership) and investment opportunity set (IOS) on earnings quality. The population in this study are companies with types of manufacturing industries listed on the Indonesia Stock Exchange in the period 2013 to 2017. The sample was obtained using a purposive random sampling method. Data analysis uses multiple linear regression. The results showed that the mechanism of good corporate governance did not affect earnings quality, and investment opportunity set (IOS) affected earnings quality.
\end{abstract}

KEYWORDS: Good Corporate Governance, Investment Opportunity Set and Earnings Quality

\section{INTRODUCTION}

According to SFAC No.1, there are two objectives of financial reporting, namely, first, providing information that is useful for investors, potential investors, creditors, and other users to make investment decisions and other similar choices. Second, provide information about the prospects of cash flow to help investors and creditors in assessing the company's net cash flow prospects.

A critical goal for profit-oriented organizations (profits) will generate profits. Therefore, the amount of profit generated can be used as a measure of company effectiveness because advantages are profits received by the company because the company has made sacrifices for the benefit of other parties.

Profit is a performance indicator that can affect economic decisions taken by users of financial statements. The benefit is essential information in investment decisions. The main goal of the company is to increase the value of the company. Profit as part of the financial statements that do not present the facts about the economic condition of the company can be doubted its quality. Benefits that do not show accurate information about management performance can be misleading to users of the report.

The parties that need financial statements consist of 2 groups, first, from within the company itself, such as manager or management. Second, from external companies or parties that are outside the company, namely investors (shareholders), creditors, and the government. In agency, the theory describes the relationship between shareholders as shareholders and management as agents. Management is a contracted party by shareholders to work in the interests of shareholders. Because they are chosen, the administration must account for all their work to shareholders.

The separation between ownership and management of the company creates conflict. The occurrence of conflicts called agency conflicts is caused by differences in interests between the agent and the principal. About this agency problem, positive accounting theory (Watts and Zimmerman, 1986) implicitly recognizes three forms of agency, namely between owners and management, between creditors and management, and between government and administration. So broadly, the principal is not only the owner of the company, but can also be a shareholder, creditor, or government.

Many cases of auditor failure in expressing the disruption of going concern company. One example is the accounting violation that occurred at one of the well-known electronics companies, namely Toshiba Corporation. The offense that happened was the management of Toshiba Corporation, especially the President and CEO of Toshiba Corporation. Hisao Tanaka and his predecessor Norio Sasaki made a deviation in recording the company's profits from 2008. The management inflated the total benefit of up to 1.2 billion US dollars. This is undoubtedly very fatal for Toshiba Corporation. The markup was forced to be allegedly to attract the interest of investors and creditors because Toshiba had closed the factory in 2016 ago. This closure occurred because of declining sales due to decreased purchasing power. Reflecting on the case above, the Toshiba factory closure in 
2016 might have been prevented earlier if the profit record had been carried out in real terms.

From this case, it can be seen that since 2008 management has tended to manipulate without making improvements. In addition to management mistakes, accountants need to get the spotlight also in this case of profit markups. The independent team that conducted the examination stated that the culture that occurred in the Toshiba Corporation was that subordinates were pressured to inflate the company's profits. Accountants, in this case, take the slightest resistance, even though if they continue to get pressure, they can report it to the Japan Accounting Standards Agency (www. Economy.kompas.com, 2017).

Based on the case above, if it is then connected with the economic occurrence in Indonesia, accountants seem to be a profession that must be responsible. Because most economic actors (public and private) do not yet understand good governance in a corporate organization. The public accountant profession has also not been optimal in realizing good corporate governance. In addition to accountants, the Japanese regulator also recommended that KAP Ernst $\&$ Young as an external auditor at the Toshiba company, be punished because of the awareness of risks and deficiencies in the audit of Toshiba, which is now involved in an accounting scandal. This is the reason why the auditor is responsible for the going concern of an entity. Granting the going concern modification opinion by the auditor is the impact of the company's doubts on being able to carry out its business continuity. Thus, the loss of public trust in company management in managing their business.

The case of cheating practices not only occurred in large companies abroad but also occurred in large companies in the country, the capital market public was again shaken by the news of the inflation of net funds at PT Kimia Farma Tbk, as written on the Tempo website on December 8, 2003, with the title "Kimia Farma Case Is a Criminal Act."

Conflicts of interest, as occurred in these cases, can be minimized previously by a monitoring mechanism that can balance the interests between management and shareholders as well as other parties. The monitoring mechanism that can be used is Good Corporate Governance. The weak implementation of the implementation of Good Corporate Governance of public companies in Indonesia, marked by the lack of transparency in corporate management which results in nervous general control and the intervention of majority shareholders in company management that can lead to conflicts of interest that significantly deviate from the norms of Good Corporate Governance (Susanti et al., 2010).

The corporate governance mechanism as a system that regulates and controls the company is expected to provide oversight to management in managing the company so that it can convince the principals that they will get a return on the funds invested.

With good corporate governance, it is expected that the quality of financial statements will be assessed well by investors. These elements and mechanisms of corporate governance can improve earnings quality and will control the nature and motivation of managers in carrying out the company's operational performance. Therefore, the implications arising from the presence of a strong GCG in a company are expected to affect the relationship between earnings management and earnings quality (Rifani, 2013).

Another study that uses other variables, namely Lestari (2016), revealed that Investment Opportunity (IOS), Liquidity, Audit Committee, Institutional Ownership had a significant effect on the company's earnings quality. The research results of the independent board of commissioners and managerial ownership do not significantly influence earnings quality. However, in contrast to Eti Kartina's research, Nikmah (2011), which shows the investment opportunity set has no significant effect on earnings quality but has a substantial impact on firm value.

Agency conflict that results in the opportunistic nature of management will result in poor earnings quality. The low quality of earnings will be able to make mistakes in the decision making of the users such as investors and creditors, so the value of the company will be reduced (Siallagan and Machfoedz, 2006).

Investment Opportunity Set (IOS) is a choice of future investment opportunities that can affect the growth of company or project assets that have a positive net present value. So that IOS has a significant role for the company because IOS is an investment decision in the form of a combination of assets owned (assets in place) and investment options in the future, where IOS will affect the value of a company (Pagalung, 2003).

Shintawati (2011) states that the ratio of the market value of equity to book value (MVE / BVE) can reflect the existence of IOS for a company. The results of his research concluded that IOS, which is proxied by MVE / BVE, has a significant effect on firm value. The higher the MVE / BVE ratio, the more senior the company value. This indicates that companies with high market value are considered reasonable by investors through high stock prices.

Various studies on earnings quality and usefulness in the context of investment decision making have been carried out. Earnings quality should be measured by several methods so that results show that it can not be concluded from only one measurement. From the phenomena that occur, conclusions can be drawn to be studied about the factors that affect the quality of corporate earnings by represented by the variable Influence of Good 
Corporate Governance Mechanisms, and Investment Opportunity Set (IOS) on Profit Quality.

\section{Problem Identification}

1. Does the mechanism of Good Corporate Governance, in this case, institutional ownership and managerial ownership, affect the quality of earnings in manufacturing companies in Indonesia?

2. Does the Investment Opportunity Set (IOS) affect the quality of earnings in manufacturing companies in Indonesia?

\section{LITERATURE REVIEW Agency Theory}

Agency theory was put forward by Jensen and Meckling in 1976. This theory states that there is a working relationship between the party that gives authority, namely the shareholders and the party that receives the power (agency), namely the manager. Jensen and Meckling (1976) define agency relationships as follows:

"We define an agency relationship as a contract under which one or more persons (the principal (s)) engage another person (the agent) to perform some service on their behalf which involves delegating some decision making authority to the agent."

The emergence of the concept of Good Corporate Governance (GCG), is the answer to the dissatisfaction of financial scientists on the performance of agency theory on a practical level. There are four main components needed in the concept of GCG, namely, fairness, transparency, accountability, and responsibility. These four components are essential because the consistent application of GCG principles has been proven to improve the quality of financial statements as well as noting that the laws of GCG that are applied consistently can become constraints on performance engineering activities that result in financial statements not reflecting the fundamental value of the company.

Performance engineering, known as earnings management, is in line with agency theory, which emphasizes the importance of company owners (principles) of handing over corporate governance to professionals who understand and understand how to run a business.

In a modern economy, management and corporate management are increasingly separated from company ownership. This is in line with Agency Theory, which emphasizes the importance of company owners (shareholders) handing over the control of the company to professionals (called agents) who are more understanding in running their daily business. The purpose of separating management from company ownership is so that the owner of the company gets the maximum possible profit at the lowest possible cost by managing the company by professionals.

\section{Profit Quality}

According to Schipper and Vincent (2003), in Novianti (2012), earnings quality is the amount that can be consumed in one period by keeping the company's ability at the beginning and end of the period to remain the same. For investors, earnings reports are considered to have information to analyze shares issued by issuers.

According to Dechow et al., (1995), in Paramitha (2012), to measure earnings quality through discretionary accruals, the Modified Jones Model is used, which is calculated by excluding total accruals (TACC) and nondiscretionary accruals (NDACC).

\section{Good Corporate Governance}

Good corporate governance is defined as a company's internal control system that has the goal of managing significant risks to meet its business objectives through securing company assets and increasing the value of shareholders' investments in the long run. Corporate governance is a system where business companies are directed and controlled (Hari Setiyawati and Nengzih, 2014).

Listyaningsih (2019), corporate governance, or corporate governance is a system designed to direct the management of the company professionally based on the principles of transparency, accountability, responsibility, independence, fairness, and equality. Corporate Governance can encourage the formation of clean, transparent, and professional management work patterns.

Tanjung, Wahyudi, and Chairunesia (2019). Good Corporate Governance is a set of policies that regulate the relationships between company management, shareholders, creditors, government, employees, and internal and external stakeholders related to their rights and obligations, or in other words Good Corporate Governance. To direct and control the company to run efficiently, transparently, and consistently with the legislation. The implementation of Good Corporate Governance (GCG) is needed to fulfill the trust of the public and the international community as an absolute requirement for the industrial world to develop well and healthy with the ultimate goal of realizing stakeholder value.

\section{Investment Opportunity Set (IOS)}

According to Myers (1977), the Investment Opportunity Set (IOS) is the value of the company as a combination of assets in place (assets owned) with investment options (investment options) in the future. Furthermore, the Definition of Investment Opportunity Set (IOS) that investment choices are an opportunity to develop, but some companies cannot implement all investment opportunities in the future. 
For companies that cannot use the investment opportunity, they will experience a higher expenditure than the lost opportunity value. An increase in net fixed assets can measure investment opportunities. This is consistent with the cash flow statement format (statement of cash flow), which measures investments from long-term investments and tangible fixed assets (Ahmad, 2009).

\section{Past Research and Framework}

Research on earnings quality with useful corporate governance variables, cash flow volatility, and investment opportunity sets have been conducted before, including Paramitha Anggia (2012), Rona Naula (2015), Kurniawati (2015), Andri and Hanung (2007), Lestari S (Sestari) ( 2016), Eti Kartina (2011) and Titik Purwanti (2010).

The results of Paramitha's research (2012) that managerial ownership does not affect earnings quality. However, it is different from the effects of Rona Naula (2015), which states that the variable of good corporate governance affects the quality of earnings.

Then the constitutional ownership variable in the research of Andri and Hanung (2007) does not affect earnings quality. This is different from Kurniawati's study (2015) that constitutional ownership variable influences earnings quality. Furthermore, the variable cash flow volatility in the research Point Purwanti (2010) states that no effect on earnings quality.

Then the investment opportunity set (IOS) variable in Lestari's (2016) study suggests that the variable has a significant effect on earnings quality. This is different from research by Eti Kartina and Nikmah (2011), which states that the investment opportunity set has no impact on earnings quality.

From the theoretical explanation and the results of previous studies, the variables in this study are the Effect of Good corporate governance, Cash flow volatility, Investment Opportunity Set (IOS) as an independent variable (independent), while Profit Quality as the dependent variable (the dependent variable).

\section{Hypothesis}

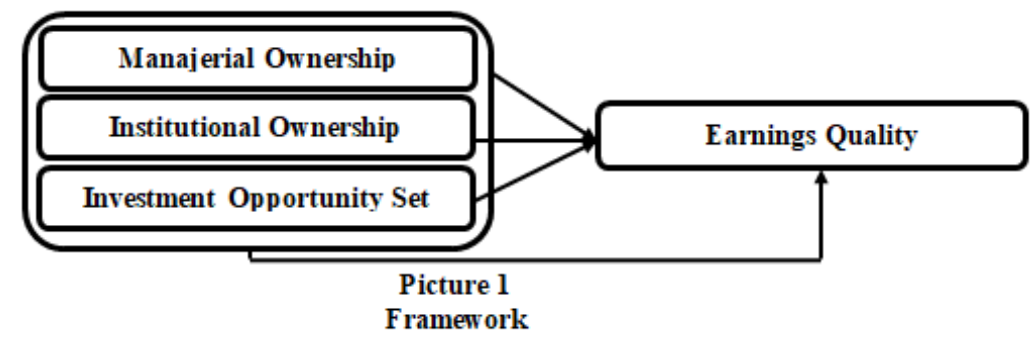

H1: Institutional ownership has a positive effect on earnings quality.

H2: Managerial Ownership has a positive effect on earnings quality.

H3: Investment Opportunity Set has a positive effect on earnings quality.

\section{RESEARCH DESIGN AND METHOD}

Operationalization of Variables and Measurement of Variables

Table1. Operationalization of Variables and Measurement of Variables

\begin{tabular}{|c|c|c|c|}
\hline Variable & Dimension & Indicator & Scale \\
\hline Earnings Quality & $\begin{array}{l}\text { 1. Total accrual } \\
\text { 2. Non Discretionary } \\
\text { Accruals } \\
\text { 3. Discretionary } \\
\text { Accruals }\end{array}$ & 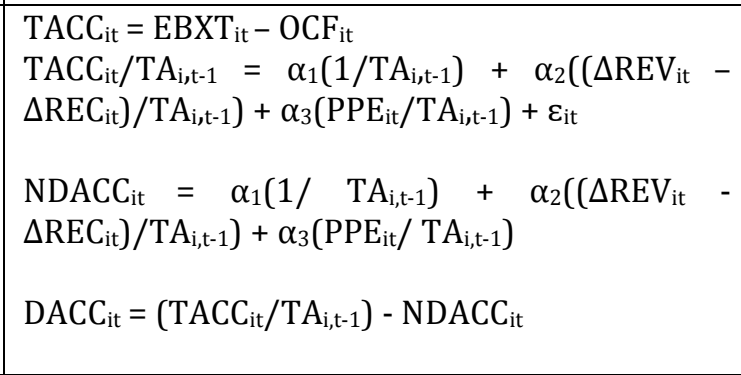 & Ratio \\
\hline $\begin{array}{l}\text { Good corporate } \\
\text { governance }\end{array}$ & $\begin{array}{l}\text { 1. Institutional } \\
\text { ownership } \\
\text { 2. Managerial } \\
\text { ownership }\end{array}$ & $\begin{array}{l}\text { 1. Percentage of total share ownership by an } \\
\text { institution or institution outside the company } \\
\text { (institutional investors). } \\
\text { 2. Percentage of share ownership by company } \\
\text { directors (company management). }\end{array}$ & Ratio \\
\hline $\begin{array}{ll}\text { Investment } & \\
\text { Opportunity Set } \\
\text { (IOS) }\end{array}$ & $\begin{array}{l}\text { market value to book } \\
\text { value of equity }\end{array}$ & $\begin{array}{l}\text { MVE/BVE }=\text { (Number of shares outstanding } \mathrm{x} \\
\text { closing price) / (total equity) }\end{array}$ & Ratio \\
\hline
\end{tabular}




\section{Population and Research Samples}

The population in this study are all manufacturing companies listed on the Indonesia Stock Exchange. This study uses secondary data from the financial statements of manufacturing companies in 2013 2017. Data in this study were taken by purposive sampling method, with the following criteria:

1. Manufacturing company

2. Publish financial statements in rupiah and issue audited financial statements as of December 31 .

3. No de-listing during 2013 - 2017.

4. Have complete data following the needs of the author.

\section{Data Analysis Method}

Data analysis was performed using the SPSS 23 program which included analysis as follows:

1. Test Descriptive Statistics
2. Classical Assumption Test consisting of, Normality Test, Multicolonity Test, Heteroscedasticity Test, and Autocorrelation Test

3. Feasibility Test Model consisting of Analysis of the Determination Coefficient (R2 test), Simultaneous Regression Coefficient Test (F Test) and Partial Test (t Test)

\section{RESEARCH RESULTS AND DISCUSSION Description of Research Object}

Based on data obtained from the official website of the Indonesia Stock Exchange or http://www.idx.co.id, it is known that the companies that entered the criteria in purposive sampling during the study year (2013-2017) were 26 companies. Criteria specified in sample selection:

Table 2. Sample Selection Results

\begin{tabular}{|l|l|}
\hline Results of Determination of Sample & Criteria Amount \\
\hline 1. Manufacturing companies listed on the Indonesia Stock Exchange & 156 \\
2. Companies that were delisted during the research year & \\
3. Companies that issue financial statements in foreign currencies \\
4. Companies that publish Annual Reports are incomplete during the \\
$\begin{array}{l}\text { research year } \\
\text { 5. Companies that do not have stock price records at the time of closing } \\
\text { and earnings per share }\end{array}$ & $(24)$ \\
6. Companies that do not have complete data on research & $(26)$ \\
\hline Companies that meet the criteria & $(49)$ \\
\hline Number of Samples (26x5years) & 26 \\
\hline
\end{tabular}

Test Assumptions and Quality of Research Instruments Descriptive statistics

Table 3 Descriptive Statistics Test Results Descriptive Statistics

\begin{tabular}{|l|l|l|l|l|l|}
\hline & Minimum & $\begin{array}{l}\text { Maximu } \\
\mathrm{m}\end{array}$ & Mean & Std. Deviation & $\mathrm{N}$ \\
\hline DACC & -4.57 & -.84 & -2.0789 & .72067 & 130 \\
INST & .7439 & 100 & 1.0673 & 1.08520 & 130 \\
MANJ & -.67 & 76 & 4.3861 & 12.39943 & 130 \\
IOS & .34 & 1358 & 73.0772 & 359.54904 & 130 \\
\hline
\end{tabular}

The table above shows a general description of maximum amount of 100 owned by Indocement the descriptive statistics of the dependent and independent variables. Based on the table above, it can be explained:

Earnings Quality Variables range in value from 4.57 to -0.84 . The lowest cost is -4.57 owned by the company PT Charoen Pokphand Indonesia Tbk in 2017 and the maximum value of -0.84 by PT DaryaVaria Laboratoria Tbk. The mean or average earnings quality variable is -2.0789 , and the standard deviation is 0.72067 .

Descriptive statistical analysis results of Institutional Ownership showed a minimum value of 0.74 by PT Lionmesh Prima Tbk in 2013 and a

Tunggal Prakarsa Tbk, Holcim Indonesia Tbk, Arwana Citramulia Tbk, Champion Pacific Indonesia Tbk, Charoen Pokphand Indonesia Tbk, Japfa Comfeed Indonesia Tbk, Astra Otoparts Tbk, PT Selamat Sempurna Tbk, Trident International Tbk, Supreme Cable Manufacturing \& Commerce, Three Pillars of Prosperous Food Tbk, Delta Djakarta Tbk, Indofood CBP Sukses Makmur Tbk, Multi Bintang Indonesia Tbk, Darya-Varia Laboratoria Tbk, Kalbe Farma Tbk, Tempo Scan Pacific Tbk, Mandom Indonesia Tbk, Unilever Indonesia Tbk from 2013 to 2017. The mean value or average institutional 
ownership is 1.0673 , with a standard deviation of 1.08520

The Managerial Ownership Variable shows a minimum value of -0.67 by PT Gudang Garam Tbk in 2016 and a maximum amount of 76.00 by PT Berlina Tbk in 2014 and 2015. The mean or average cost of managerial ownership is 4.3861 , and the standard deviation is 12,40 .

The results of the descriptive statistical analysis of the Investment Opportunity Set (IOS) variable showed a minimum value of 0.34 by PT Gajah Tunggal Tbk in 2015 and a maximum amount of 1,358.53 owned by PT Berlina Tbk in 2014. The mean or average IOS value was 73,0772 , and the standard deviation of 359.55 .

\section{Classical Assumption Test Normality test}

The normality test aims to determine whether a data distribution is healthy or not. Testing the normality of data in this study using a graph that results from the standard probability plot and nonparametric statistical analysis Kolmogorov-Smirnov Z (1-Sample K-S).

From the test results, it is known that the Asymp value model. Sig. (2tailed) $=0.125$, then according to the provisions of $0.125>0.05$, the residual value is normal. Then the data in the model can be said to be normally distributed, and the regression model can be used for further testing. So it can be concluded that the data tested were normally distributed.

\section{Heteroscedasticity Test}

From the glacier test results on the data, note that the correlation value of variables with Unstandardized Residuals has a significance value of more than 0.05 . Because the significance is more than 0.05 , it can be concluded that there is no heteroscedasticity problem in the regression model.

\section{Multicollinearity Test}

Based on the results of the output, it is explained that the value of the independent variable is tolerance $<0.01$ and VIF $>10$, so it can be said that multicollinearity occurs. But this often happens in studies that use multiplication regression models because multicollinearity can be caused by the effect of a combination of two or more independent variables (Ghozali, 2013).

\section{Autocorrelation Test}

From the results of the above output, the DW value generated from the regression model is 1,812 . Then the value is compared with $\mathrm{dl}$ and $\mathrm{du}$. From the Durbin-Watson table with a significance level of 5\% and for $\mathrm{n}=130, \mathrm{k}=4$ is obtained $\mathrm{dl}=1.6508, \mathrm{du}=$ 1.7774. With the above data, then calculated and compared with the Durbin-Watson table in table 4.6 is 1,812 between $\mathrm{du}$ and four $\mathrm{du}$, ie, $1.7774<1.812$ $<2.22226$, the null hypothesis is accepted, which means there is no autocorrelation in regression.

\section{Hypothesis test \\ Determination Coefficient Analysis (R2) \\ Table 4. Results of the Determination Coefficient Analysis}

Model Summaryb

\begin{tabular}{|l|l|l|l|l|l|}
\hline Model & $\mathrm{R}$ & R Square & $\begin{array}{l}\text { Adjusted } \\
\text { Square }\end{array}$ & $\begin{array}{l}\text { Std. Error of } \\
\text { the Estimate }\end{array}$ \\
\hline 1 & $.443^{\mathrm{a}}$ & .196 & .175 & .65634 \\
\hline
\end{tabular}

a. Predictors: (Constant), IOS, INST, MANJ

b. Dependent Variable: DACC

Based on the results of the analysis using the coefficient of determination test (R2) contained in the table shows that the value of Adjusted $\mathrm{R}$ Square is 0.196 , this means that $19.6 \%$ of the dependent variable in this study is the Profit Quality can be

explained by the variable mechanism of Good Corporate Governance and Investment Opportunity Set (IOS) of $19.6 \%$, while the rest $(100 \%-19.6 \%=$ $80.4 \%)$ is explained by other factors outside this study.

\section{Simultaneous Regression Coefficient Test (Test F)}

Table 5. Test Results F

ANOVA $^{\mathrm{a}}$

\begin{tabular}{|ll|l|l|l|l|l|}
\hline Model & & Sum of Squares & $\mathrm{df}$ & Mean Square & $\mathrm{F}$ & Sig. \\
\hline \multirow{4}{*}{1} & Regression & 13.150 & 4 & 3.288 & 7.632 & $.000^{\mathrm{b}}$ \\
& Residual & 53.848 & 125 & .431 & & \\
& Total & 66.998 & 129 & & & \\
\hline
\end{tabular}

a. Dependent Variable: DACC

b. Predictors: (Constant), IOS, INST, MANJ 
Prob value $F$ count (sig.) In the above table is 0.00 less than the 0.05 significance level so that it can be concluded that the estimated linear regression model is appropriate to be used to explain the Effect of Good Corporate Governance Mechanisms and Investment Opportunity Set on Profit Quality and can also it is said that all independent variables jointly influence the dependent variable.

\section{Regression Coefficient Test (t Test)}

Table 6. Regression Coefficient Test Results

\begin{tabular}{|l|l|l|l|l|l|l|}
\hline \multicolumn{2}{|l|}{} & \multicolumn{2}{l}{$\begin{array}{l}\text { Unstandardized } \\
\text { Coefficients }\end{array}$} & $\begin{array}{l}\text { Standardize } \\
\text { d } \\
\text { Coefficients }\end{array}$ & T & Sig. \\
\hline \multirow{2}{*}{} & B & $\begin{array}{l}\text { Std. } \\
\text { Error }\end{array}$ & Beta & & \\
\hline \multirow{4}{*}{1} & (Constant) & -1.727 & .106 & & -16.355 & .000 \\
\cline { 2 - 7 } & INST & -.054 & .054 & -.081 & -1.003 & .318 \\
\cline { 2 - 7 } & MANJ & -.001 & .005 & -.018 & -.215 & .830 \\
\cline { 2 - 7 } & IOS & .000 & .000 & -.178 & -2.059 & .042 \\
\hline
\end{tabular}

a. Dependent Variable: DACC

The regression equation is as follows:

$\mathrm{DACC}=-1,727-0,054 \mathrm{INST}-0,001 \mathrm{MANJ}+0,000$ $\mathrm{IOS}+\varepsilon$

Based on the results of the analysis table using the $t$ test, it can be concluded:

a. A constant of -1.727 means that if the value of the Good Corporate Governance Mechanism, Cash Flow Volatility and Investment Opportunity Set is 0 , the Profit Quality value is $-1,727$.

b. The regression results show the value of the Institutional Ownership variable of -0.054 . This means that every 1 unit increase in the level of institutional ownership, it can reduce the number of discretionary accruals by 0.054 so that the quality of earnings rises assuming other independent variables remain. The variable of institutional ownership has a significant probability value of $0.318>0.05$, which means that institutional ownership does not affect earnings quality.

c. The regression coefficient shows the value of the Managerial Ownership variable of -0.054 . This means that each increase of 1 unit of managerial ownership level, it can reduce the number of discretionary accruals by 0.054 so that the quality of earnings rises assuming other independent variables remain. Managerial ownership variable significance level of 0.830 is higher than 0.05 , so it can be concluded that managerial ownership does not have a significant effect on earnings quality.

d. The regression coefficient shows the value of the Investment Opportunity Set (IOS) variable of 0,000 . This means that for every 1 unit increase in the Investment Opportunity Set (IOS) level, it can increase the value of discretionary accruals by 0,000 so that the quality of earnings decreases assuming other independent variables remain. The Investment Opportunity Set variable has a significance value of 0.042 , which is smaller than $0.05(0.042<0.05)$. So it can be concluded that the Investment Opportunity Set has a significant effect on earnings quality.

\section{Discussion \\ Effect of Institutional Ownership on \\ Earnings Quality}

Regression results in this study indicate that the variable Institutional Ownership of Earnings Quality on the t-test results obtained a p-value significance of 0.318 is more significant than $\alpha=0.05$. It can be concluded that the first hypothesis (H1 is rejected). It can also be interpreted that the institutional ownership variable does not affect earnings quality. The possibility that institutional ownership does not affect the quality of earnings does not originate from the many levels of institutional ownership in the company, but the less optimal level of supervision. According to Dewi (2018), company performance can be influenced by institutional ownership, which, based on theory, states that institutional ownership will encourage more optimal oversight. Also, institutional investors have a primary focus on market response through increasing share prices so that institutional ownership with earnings quality is unrelated.

The results of this study are in line with Glovita (2010), which states that institutional ownership does not affect the quality of corporate earnings. The accounting statements contained in the financial statements are the responsibility of management for the management of the company's resources. Institutional ownership will use the financial statements as a basis for making decisions without having the power to influence what management reports in the financial statements. Financial statements are a product of control so that institutional ownership outside the company cannot affect what management says in the financial statements, including earnings quality. Other research that is in line, namely Andri and Drs Hanung (2007), states that institutional ownership does not affect 
earnings quality (discretionary accrual). This result also supports the research of Noviana and Khafid (2014), which indicates that the institution is the owner who focuses more on current earnings.

However, this study is different from the results of research by Givoly et al. (2010), which states that public ownership of shares will improve the quality of corporate earnings, and also study by Paramitha (2012) says that institutional ownership positively influences the quality of revenues received.

\section{Effect of Managerial Ownership on Earnings Quality}

The second hypothesis (H2) which states that managerial ownership does not affect earnings quality. With a significance value of 0.830 , which is higher than $\alpha=0.05, \mathrm{H} 2$ is not accepted. The results of this study indicate that managerial ownership has no effect on earnings quality measured by discretionary accruals. The reason managerial ownership does not affect earnings quality is that management ownership is so small that management is less able to influence decision making in running company operations. Then, pressure from the capital market causes companies to choose accounting methods to increase the company's profits to attract capital from outside even though it does not reflect the company's actual economic situation (Lestari, 2016). The results of this study support the research by Paramitha Anggia (2012), which states that managerial ownership does not affect earnings quality. With a minimal number of shares, the conflict of interest between the owner and the manager is not over. Managers will still be motivated to do earnings management to meet their welfare. Novita's research (2010) also shows that managerial ownership has no significant effect on earnings quality. This is due to the small proportion of share ownership allocated to managers because company ownership in Indonesia tends to be centralized in one group. Empirically found evidence that companies whose property is more spread give more exceptional rewards to management so that it can reduce the motivation of managers to manipulate earnings.

Thus, the greater managerial ownership will be prone to management actions to engineer earnings on the financial statements that cause the earnings quality on the report to be low or not reflect the real conditions because the manager's works tend to use company accruals to report higher profits (Siallagan and Machfoedz, 2006).

However, the results of this study are not in line with the results of Eti Kartina's research (2011) which states that managerial ownership influences the quality of earnings received, which means that the higher the ownership of shares owned by managerial companies, the quality of reported earnings more qualified so that the market responds to announcements from reports earnings quality is getting better (Suranta, 2006), this may be due to the managerial as well as the manager as well as the owner so that in running the company more careful.

\section{Effect of Investment Opportunity Set on Profit Quality}

The third hypothesis (H3), which states that the investment opportunity set has a positive impact on earnings quality. With a significance value of 0.042 , which is smaller than $\alpha=0.05, \mathrm{H} 3$ is accepted. The results of this data processing show that the Investment Opportunity Set has a positive effect on earnings quality. Then it can be concluded that IOS has a significant positive impact on earnings quality as measured by discretionary accruals, which means companies with excellent investment opportunity set levels are likely to have top prospects for company growth in the future resulting in earnings quality that is beneficial for decision making.

The results of this study are consistent with Rachmawati and Triatmoko (2007), Paramitha Anggia (2012), who discovered the influence of IOS on earnings quality. Then another study that states the impact of IOS variables on earnings quality is Lestari (2016). IOS's effect on earnings quality is due to the investment opportunity set in implicating the value of assets and the value of the company's opportunity to grow in the future.

The results of this data processing are not in line with Kartina and Nikmah (2011) which states that the Investment Opportunity Set (IOS) does not affect earnings quality, meaning that the market does not consider investment spending as a matter of consideration in determining the quality of earnings announced by the company.

\section{CONCLUSIONS AND RECOMMENDATIONS \\ Conclusion}

Based on the results of the analysis conducted in this study, it can be concluded that:

1. Institutional ownership does not affect earnings quality.

2. Managerial ownership does not affect the quality of earnings.

3. Investment Opportunity Set (IOS) affects the quality of earnings.

\section{Suggestion}

This study has several limitations that may lead to imperfect research results. Therefore, the researcher proposes the following recommendations:

1. Further researchers are advised to take samples in other types of industries outside of manufacturing.

2. There are several types of earnings quality measurement, but this study only uses one proxy 
so that the results may also be different if measured using another surrogate.

3. This study only uses independent variables, namely the mechanism of good corporate governance (managerial ownership and institutional ownership), cash flow volatility, and investment opportunity set. Future studies are expected to add other independent variables that can affect earnings quality.

\section{REFERENCES}

1. Ahmad, Rizal. 2009. "Pengaruh profitabilitas dan investment opportunity set terhadap kebijakan deviden tunai”. ISSN: 1979 - 5408 Vol. 2.

2. Andri Rachmawati Dan Hanung Triatmoko. 2007. "Analisis Faktor-Faktor Yang Mempengaruhi Kualitas Laba Dan Nilai Perusahaan". Simposium Nasional Akuntansi X Makassar, 26-28 Juli.

3. Ani Kurnia dan Ari Dewi. 2017. "Pengaruh Mekanisme Good Corporate Governance Terhadap Kualitas Laba Akuntansi Pada Perusahaan Manufaktur di Bursa Efek Indonesia”. Assets, Vol. 7, No. 1, Juni 2017: 1740.

4. Boediono, Gideon. 2005. Kualitas Laba: Studi Pengaruh Mekanisme Corporate Governance Dan Dampak Manajemen Laba Dengan Menggunakan Analisis Jalur. Simposium Nasional Akuntansi (SNA) VIII Solo.

5. Dea Imanta Dan Rutji Satwiko. 2011. FaktorFaktor Yang Mempengaruhi Kepemilikan Managerial. Jurnal Bisnis Dan Akuntansi Vol. 13, No. 1, April 2011, Hlm. 67-80.

6. Dechow, P. M., Sloan, R.G., Sweeney, A.P, 1995. Detecting Earnings Management. The Accounting Review 70, 193-225.

7. Dewi, 2018. "Analisis Pengaruh Growth, Ukuran Perusahaan, dan Corporate Governance Terhadap Kualitas Laba. Institut Agama Islam Negeri Surakarta.

8. Ghozali, Imam. 2013. Aplikasi Analisis Multivariate dengan Program SPSS. Edisi Ketujuh. Semarang : Badan Penerbit Universitas Diponegoro.

9. Givoly Dan, Hayn Carla K. Dan Katz Sharon P. 2010. Does Public Ownership of Equity Improve Earnings Quality?, The Accounting Review: 85, 1: 195-225.

10. Glovita. 2010. Pengaruh Kepemilikan Manajerial, Kepemilikan Institusional, Leverage, dan Growth terhadap Kualitas Laba Perusahaan. Tesis S2, Universitas Sebelas Maret Surakarta.

11. Hari Setiyawati dan Mutia Nengzih. 2014. "The Effect of Implementation of Good Corporate Governance and the Effectiveness of Internal Control System Disclosure of Environmental accounting and Its Implications On the Company Performance".

12. Ikatan Akuntan Indonesia. 2010. Standar Akuntansi Keuangan. Jakarta: Salemba Empat.

13. Ikatan Akuntan Indonesia. 2013. Standar Akuntansi Keuangan Entitas Tanpa Akuntabilitas
Publik (SAK ETAP). Jakarta: Ikatan Akuntan Indonesia.

14. Jensen, M., 1986, "Agency Cost of Free Cash Flow, Corporate Finance, and Takevers". American Economics Review, Vol. 76, hlm. 323326.

15. Jensen, Michael C. dan William H. Meckling. 1976. "Theory of the Firm: Managerial Behaviour, Agency Costs and Ownership Structure".

16. Kartina, Eti dan Nikmah. 2011. Pengaruh Corporate Governance, Invesment Opportunity Set(IOS) Terhadap Kualitas Laba dan Nilai Perusahaan. Jurnal Akuntansi Vol 1, p92-121.

17. Kurnia, Elly. 2010. Analisis Pengaruh Volatilitas Arus Kas, Magnitude accrual, Volatilitas Penjualan, Leverage, dan Siklus Operasi terhadap Kualitas Laba. Universitas Muhammadiyah. Surakarta.

18. Kurnia, Ivan Dan Sufiyati. Pengaruh Ukuran Perusahaan, Leverage, Risiko Sistematik, Dan Investment Opportunity Set Terhadap Earnings Response Coefficient Pada Perusahaan Manufaktur Yang Terdaftar Di Bursa Efek Indonesia Pada Tahun 2012-2014. Jurnal Ekonomi. 20(3) (2015): 463-478.

19. Kurniawati. 2015. Pengaruh Mekanisme Good Corporate Governance, Set Kesempatan Investasi (IOS) Dan Ukuran Perusahaan Terhadap Kualitas Laba.

20. Lestari Setianingsih. 2016. Pengaruh Investment Opportunity Set, Likuiditas dan Good Corporate Governance terhadap Kualitas Laba pada Perusahaan.

21. Listyaningsih, Fransisca and Putri Renalita Sutra Tanjung. (2019). The Effect Of Good Corporate Governance, Company Sizes, And Leverage Of Tax Avoidance. EPRA International Journal of Multidisciplinary Research (IJMR). Volume: 5 | Issue: 11 | November 2019

22. Myers, S.C (1977). Capital Of Corporate Borrowing. Journal Of Financial Economics (5), 147-175.

23. Noviana. 2014. Pengaruh Good Corporate Governance terhadap Nilai Perusahaan dengan Kualitas Laba sebagai Variabel Intervening. Acconting Analysis Journal. AAJI 3(1)(2014).

24. Novianti, Rizki. 2012. Kajian Kualitas Laba pada Perusahaan Manufaktur yang terdaftar di Bursa Efek Indonesia. Accounting Analysis Journal, 1(2): h:1-6.

25. Pagalung, Gagaring. 2003. "Pengaruh Kombinasi Keunggulan dan Set Kesempatan Investasi (IOS)”. Jurnal Riset Akuntansi Indonesia, Vol. 6(3).

26. Paramitha Anggia Putri, Abdul Rohman 2012. Analisis Pengaruh Investment Opportunity Set, dan mekanisme Corporate Governance teradap kualitas laba dan nilai perusahaan. Dipenegoro Journal of Accounting Vol.01 No.02 Hal 1-14.

27. Peraturan Menteri BUMN Nomor: PER01/MBU/2011. Penerapan Tata Kelola yang Baik (GCG) pada BUMN. 
28. Rifani, Aulia. 2013. Pengaruh Good Corporate Governance terhadap Hubungan Manajemen Laba dan Kualitas Laba. Skripsi. Universitas Negeri Padang.

29. Schipper, K., \& Vincent, L. (2003) "Earnings quality”. Accounting Horizons, 17,97-110.

30. Scott, R. William. 2015. Financial Accounting Theory. Sevent Edition. Pearson Prentice Hall: Toronto.

31. Shintawati, Vidya Ria. 2011. "Pengaruh Board Diversity, Investment Opportunity Set (IOS), dan Kinerja Keuangan terhadap Nilai Perusahaan yang Terdaftar di Bursa Efek Indonesia Tahun 2008”. Fakultas Ekonomi Universitas Sebelas Maret.

32. Siallagan, Hamonangan dan Mas'ud Machfoedz, "Mekanisme Good Corporate Governance, Kualitas Laba dan Nilai Perusahaan, "Simposium Nasional Akuntansi IX Padang, 2006.

33. Tanjung, $P . \quad R$. S., Wahyudi, S. M., \& Chairunesia, W. (2019). Effect Of Corporate Social Responsibility Disclosure And Good Corporate Governance Implementation On Response Coefficient Earnings (Asean Country Cross Study 2016-2018). Archives of Business Research, 7(7), 370-383.

34. Tanjung, P.R.S., Wahyudi, S.M. (2019). Analysis the Effect Disclosure of Sustainability Report, Economic Value Added and Other Fundamental Factors of Companies on Company Value, International Journal of Academic Research in Accounting, Finance and Management Sciences 9 (2): 237-249.

35. Titik purwanti. 2010. Analisis pengaruh volatilitas arus kas, besaran akrual, volatilitas penjualan, leverage, siklus operasi, ukuran perusahaan, umur perusahaan, dan likuiditas terhadap kualitas laba. UNS-Pascasarjana Prog. Studi Akuntansi-S.4307036-2010. Tesis S2, Universitas Sebelas Maret.

36. Watts, Ross L. dan Jerold L. Zimmerman (1986). Positive Accounting Theory. USA: Prentice-Hall. 